\title{
Comparison of bioactivities, binding properties and intrafollicular levels of bovine follistatins
}

\author{
Claire Glister, Simon J Sunderland ${ }^{1}$, Maurice P Boland ${ }^{1}$, James J Ireland ${ }^{2}$ and Phil G Knight \\ School of Biological Sciences, University of Reading, Reading RG6 6UB, UK, ${ }^{1}$ Faculty of Veterinary Medicine, \\ University College Dublin, Dublin, Ireland and ${ }^{2}$ Department of Animal Science, Michigan State University, \\ East Lansing, Michigan 48824, USA
}

Correspondence should be addressed to P G Knight; Email: p.g.knight@reading.ac.uk

\begin{abstract}
Five isoforms of follistatin (FST) $\left(M_{r} 31,33,35,37\right.$, and $\left.41 \mathrm{kDa}\right)$ were purified from bovine follicular fluid (bFF). Comparison of their activin and heparan sulphate proteoglycan (HSP) binding properties and biopotencies in the neutralisation of activin A action in vitro revealed that all five isoforms bound activin $\mathrm{A}$, but they did so with different affinities. Only the $31 \mathrm{kDa}$ isoform (FST-288) bound to $\mathrm{HSP}$. FST-288 also showed the greatest biopotency, and the 35 and $41 \mathrm{kDa}$ isoforms were the least potent. To determine whether bovine follicle development is associated with changing intrafollicular FST and activin profiles, we analysed bFF from dominant follicles (DFs) and subordinate follicles (SF) collected at strategic times during a synchronised oestrous cycle. Total FST, activin A and activin AB were measured by immunoassay, whereas individual FST isoforms were quantified by immunoblotting. Follicle diameter was positively correlated with oestrogen:progesterone ratio $(r=0.56)$ in bFF but negatively correlated with activin $A(r=-0.34)$, activin $A B$ $(r=-0.80)$ and 'total' FST $(r=-0.70)$ levels. Follicle diameter was positively correlated with the abundance of the $41 \mathrm{kDa}$ isoform $(r=0.59)$ but negatively correlated with the abundance of the 33 and $31 \mathrm{kDa}$ isoforms $(r=-0.56$ and $r=-0.41$ respectively). Both follicle statuses (DF and SF) and cycle stage affected total FST, activin A and activin B levels, whereas follicle status, but not cycle stage, affected the abundance of the 41, 37, 33 and 31 kDa FST isoforms. Collectively, these findings indicate that intrafollicular FST isoforms, which differ in their ability to bind and neutralise activins and to associate with cell-surface proteoglycans, show divergent changes during follicle development. Enhanced FST production may play an important negative role, either directly or via the inhibition of the positive effects of activins, on follicle growth and function during follicular waves.

Reproduction (2015) 150 85-96
\end{abstract}

\section{Introduction}

Since the discovery and characterisation of inhibins and activins more than 25 years ago, numerous studies have investigated the involvement of these structurally related yet reciprocally acting proteins in the regulation of ovarian function (for reviews, see Woodruff \& Mather (1995), Knight \& Glister (2001), Findlay et al. (2002), Phillips (2005) and Knight et al. (2012)). Regulatory roles that impact follicle development are manifested at both the anterior pituitary level (i.e. the modulation of FSH secretion) and the intraovarian level, with activin exerting local autocrine/paracrine stimulatory effects that are opposed by inhibin and/or the activin-binding protein follistatin (FST). For instance, in vitro studies have implicated activin as being an important promoter of follicle growth/survival by virtue of its ability to up-regulate cell proliferation, to up-regulate folliclestimulating hormone $(\mathrm{FSH})$ receptor expression and to enhance basal and $\mathrm{FSH}$-induced oestrogen production by granulosa cells while simultaneously inhibiting progesterone production. In addition, activin suppresses luteinizing hormone (LH)-induced androgen production by theca cells. These actions can be reversed by inhibin and/or FST. Inhibin antagonises activin signalling via competitive binding to the type 2 activin receptor on the cell surface, whereas FST inhibits activin signalling by acting as a high-affinity activin-binding protein (de Winter et al. 1996, Schneyer et al. 1997, Sugino et al. 1997, Harrison et al. 2006).

FST is a cysteine-rich, monomeric glycoprotein that is encoded by a single gene that is highly conserved amongst vertebrates (Schneyer et al. 1997, Sugino et al. 1997, Hedger \& de Kretser 2013). FST was first isolated from ovarian follicular fluid based on its ability to suppress FSH secretion by pituitary cells (Robertson et al. 1987). Multiple isoforms of FST protein exist; up to six different isoforms have been identified in ovarian follicular fluid (Sugino et al. 1997, Glister et al. 2006). These are generated by alternate mRNA splicing to yield two core proteins (FST-288 and FST-315). FST-315 can undergo posttranslational cleavage of the 
carboxy-terminal sequence to yield FST-303. These three 'core' proteins can also be glycosylated to produce the six isoforms that have been identified in porcine (Sugino et al. 1993, 1997) and bovine (Glister et al. 2006) follicular fluid. It has previously been reported that FST can bind to heparan sulphate proteoglycans (HSPs) on the surface of granulosa and other cells. The shorter (FST288) forms bind with much higher affinity than the longer (FST-315) forms do, which implies different roles in modulating activin function (Nakamura et al. 1991, 1997). Moreover, the binding of FST-activin complexes to cell surface proteoglycans facilitates endocytosis and subsequent lysosomal degradation (Hashimoto et al. 1997). In addition to their recognised roles in reproductive tissues, activins and FST are important regulators of haematopoiesis, immunoregulation, inflammation, wound healing and fibrosis (for a review, see Hedger \& de Kretser (2013)).

With regard to previous studies on the ovarian inhibin-activin-FST system in various species, an important caveat is that a large majority of the studies have been carried out using just one FST form (recombinant human (rh)FST-288) and one activin form ( $r$ activin $A$ ), both of which are widely available to the research community primarily from commercial sources. In addition, very little information is available on the relative abundance of individual isoforms of FST and activin in different biological compartments, including ovarian follicular fluid. With this in mind, the primary objective of the present study was to purify native FST isoforms from pooled bovine follicular fluid (bFF) to allow a direct comparison of their activin and HSP binding properties as well as an analysis of their biopotencies in reversing the inhibitory effect of activin A on thecal androgen production in vitro. In addition, we used quantitative immunoanalytical techniques (ELISA, western blotting) to test the hypothesis that post-emergence antral follicle growth in oestrous cyclesynchronised cattle is associated with changing intrafollicular levels of different isoforms of FST and activin, which reflects the differential production and roles of these proteins in follicle selection and dominance in this monovulatory species.

\section{Materials and methods \\ Purification of FST isoforms from pooled bFF}

Pooled bFF (protein content $65 \mathrm{mg} / \mathrm{ml}$ ) was collected by needle aspiration of non-cystic follicles visible on the surface of cattle ovaries obtained from the slaughterhouse. bFF was stored at $-80{ }^{\circ} \mathrm{C}$ in the presence of a protease inhibitor $(0.005 \% \mathrm{w} / \mathrm{V}$ phenylmethylsulphonylfluoride). After thawing, bFF was centrifuged (at $20000 \mathrm{~g}$ for $30 \mathrm{~min}$ at $4{ }^{\circ} \mathrm{C}$ ), and the supernatant $(200 \mathrm{ml}$ ) was applied to an anti-FST immunoaffinity column. This was prepared by coupling $10 \mathrm{mg}$ of a 1:1 mixture of two anti-FST MAb (clones FST 1/1 and 8/1; gift from Prof. N P Groome, Oxford Brookes University, Oxford, UK) to $5 \mathrm{ml}$ of n-hydroxysuccinamide-activated sepharose beads (GE Healthcare Ltd, Amersham, UK), according to the manufacturer's instructions.

bFF (200 ml; $13 \mathrm{~g}$ protein) was cycled through the anti-FST immunoaffinity column at a flow rate of $0.5 \mathrm{ml} / \mathrm{min}$ overnight at $4{ }^{\circ} \mathrm{C}$. After washing the column with $100 \mathrm{ml} \mathrm{PBS}$, the bound fraction (containing multiple FST isoforms as well as activins bound to FST) was eluted using three column volumes (15 $\mathrm{ml}$ ) of $8 \mathrm{M}$ urea. The urea solution was deionised by passing it through a mixed bed ion exchange resin (Monobed, Amberlite, Fisher Scientific Ltd, Loughborough, UK) immediately before use. After immunoaffinity chromatography, subsequent steps were used to isolate the FST isoforms based on the method described by Sugino et al. (1993) with some modifications. CHAPS $(0.05 \% \mathrm{w} /$ $\checkmark$ final) and Tris- $\mathrm{HCl}(\mathrm{pH} \mathrm{7.8)}$ pre-set crystals (20 mM final) were added to the fraction eluted from the immunoaffinity column, and the solution was applied to a FPLC Mono Panion exchange column $(5 \times 100 \mathrm{~mm}$; Pharmacia Ltd), which was pre-equilibrated with $20 \mathrm{mM}$ Tris- $\mathrm{HCl}(\mathrm{pH} 7.8)$ and $0.05 \% \mathrm{w} / \mathrm{v}$ CHAPS. Four distinct peaks (A, B, C and D) were eluted with a linear gradient from 0 to $1 \mathrm{M} \mathrm{NaCl}$ in $20 \mathrm{mM}$ Tris/ $\mathrm{HCl}(\mathrm{pH} 7.8)$ at a flow rate of $1 \mathrm{ml} / \mathrm{min}$ over $40 \mathrm{~min}$, and fractions were collected every $0.5 \mathrm{~min}$. Pooled fractions comprising each peak, plus the nonretained (NR) fraction, were further purified by reversed-phase HPLC using a Cosmosil C8 $(4.6 \times 150 \mathrm{~mm}$; Hichrom Ltd, Theale, UK) column. The column was developed with a $5 \mathrm{~min}$ linear gradient of $10-30 \%$ acetonitrile in $0.1 \%$ trifluoroacetic acid, followed by a $10 \mathrm{~min}$ gradient of $30-40 \%$ at a flow rate of $1 \mathrm{ml} / \mathrm{min}$, and fractions were collected every $0.25 \mathrm{~min}$. Highly enriched FST-containing fractions were designated as RP-HPLC peaks 1, 2, 3, 4 and 5. Throughout the purification procedure, chromatographic eluates were monitored for u.v. absorbance at $280 \mathrm{~nm}$. Fractions were also analysed for FST immunoreactivity using a two-site ELISA (see the following section on hormone immunoassays). Estimates of the total protein concentrations and final yields were based on the assumption that a $1 \mathrm{mg} / \mathrm{ml}$ solution of protein has a $280 \mathrm{~nm}$ absorbance value of 1.0.

\section{Deglycosylation of purified FST isoforms}

A $1 \mu \mathrm{g}$ aliquot of each of the purified FST isoforms was treated with a mixture of five different deglycosylation enzymes (E-DEGLY kit; Sigma) according to the manufacturer's instructions. Treated vs non-treated samples were run on SDS-PAGE and stained with silver nitrate according to the method described by Morrissey (1981).

\section{SDS-PAGE and western blotting}

Purified bovine FST fractions and bFF samples harvested from cycle-synchronised heifers (see the following section on ovarian sample collection) were analysed by SDS-PAGE/western blotting as described previously (Glister et al. 2006). SDSPAGE was performed under non-reducing conditions using $12.5 \%$ gels. Gels were either stained with Coomassie blue to detect total proteins or subjected to electrophoretic transfer to nitrocellulose membranes for the immunodetection of individual FST isoforms using a 1:1 mixture of FST MAb (clone 1/1 and clone 8/1). ${ }^{125}$ I-labelled horse anti-mouse IgG was used as a secondary antibody to detect membrane-bound anti-FST MAb 
using a phosphor screen and Phosphorimager (Molecular Dynamics Inc., Sunnyvale, CA, USA), and images were analysed using the freely available Image J version 1.32J Software. The between-gel coefficient of variation for FST band intensity averaged $10.6 \%$ based on the estimates for a pooled bFF quality-control sample included on each gel.

\section{Bioassay for FST isoform activity}

The biological potency of each purified bovine FST isoform, along with that of rhFST-288 (R\&D Systems, Abingdon, UK), was determined using an in vitro bovine theca cell bioassay based on the ability of FST to block the suppressive effect of activin on androstenedione production by LH-treated theca cells. Bovine theca cells were isolated and cultured as described previously (Glister et al. 2005). The cells were cultured under serum-free conditions for 6 days, with media being changed and treatments, including LH (150 pg/ml), being added on days 2 and 4 . Before they were added to the cells, FST and activin treatment combinations were diluted in culture medium and pre-incubated for $4 \mathrm{~h}$ at room temperature to allow any FST-activin association to occur. A near-maximally effective concentration of activin A (10 ng/ml, which gives $\sim 85 \%$ suppression of androstenedione secretion) was used, and the molar ratio of FST to activin A was adjusted to $0: 1,2: 1,4: 1,8: 1$ or 16:1. Molar ratio, rather than mass ratio, was used in order to account for the differences in molecular mass among the different FST isoforms. At the end of the culture period, conditioned media were removed and stored at $-20{ }^{\circ} \mathrm{C}$ until they were assayed for androstenedione; viable cell numbers were determined by neutral red dye uptake assay. Each experiment was repeated four times using independent batches of cells.

\section{Biacore surface plasmon resonance experiments to determine binding affinities}

To determine the binding affinity of purified FST isoforms for immobilised rh activin A and HSP, experiments were performed using a Biacore 3000 Surface Plasmon Resonance (SPR) instrument (Biacore International, Stevenage, Hertfordshire, UK). rh activin A (R\&D Systems) and HSP (Sigma) were immobilised on the surface of separate CM5 sensor chips $(\sim 500$ resonance units) according to the manufacturer's protocol (Biacore). BSA was immobilised on an adjacent lane of each chip ( $\sim 500$ resonance units) to act as an independent control for rh activin A and HSP. Purified bovine FST isoforms and rhFST-288 were passed over both chips at a flow rate of $30 \mu \mathrm{l} / \mathrm{min}$. HEPES-buffered saline $(10 \mathrm{mM}$ HEPES, $150 \mathrm{mM}$ $\mathrm{NaCl}, 3.4 \mathrm{mM}$ EDTA, $0.005 \%$ Tween20, pH 7.4) was used for a sample dilution and as a running buffer. Each FST isoform was run over immobilised rh activin A, HSP and BSA lanes at a range of concentrations $(6.25,12.5,18.75,25,37.5,50,75$ and $100 \mathrm{nmol} / \mathrm{l})$. For chip regeneration, bound FST was eluted from the rh activin A- or HSP-coated surface using $50 \mathrm{mM}$ $\mathrm{NaOH}$ and $1 \mathrm{M} \mathrm{NaCl}$. Binding curves were corrected by subtracting the blank and were evaluated using Biacore evaluation software. Each experiment was repeated at least three times, and kinetic data, including KD, were calculated using the Biacore evaluation software.

\section{Comparison of biological activities and FST binding properties of activins $A, A B$ and $B$}

The ability of rh activin A, activin AB and activin $B$ to suppress androstenedione secretion by bovine theca cells was compared by treating cells for 4 days with $0,2,10$ and $50 \mathrm{ng} / \mathrm{ml}$ of each protein. The binding affinities of rh activin $A$, activin $A B$ and activin $B$ for immobilised rhFST-288 were evaluated by Biacore SPR analysis. Bioassay and binding experiments were repeated three times.

\section{Collection of ovarian samples from oestrous cycle-synchronised cattle}

The bFF samples that were analysed for activin and FST content in the present study were collected as part of a previous investigation that focused on the analysis of inhibin and inhibin subunits (Sunderland et al. 1996). A detailed description of the animals and experimental procedures that were used to obtain the bFF samples, as well as their serum hormone profiles and concentrations of inhibins, oestradiol $\left(E_{2}\right)$ and progesterone $\left(\mathrm{P}_{4}\right)$, can be found in that publication. All of the animal work was carried out in accordance with regulations set down by the UCD BioMedical Centre, Dublin, Ireland, and by the Cruelty to Animals Act (Ireland).

Briefly, oestrous cycles of 28 crossbred beef heifers aged 15-18 months were synchronised using a 10-day progestagen implant regimen (Crestar, Intervet Ireland Ltd, Dublin, Ireland) with PGF2 $\alpha$ analogue (PG; Prosolvin, Intervet Ireland Ltd) that was administered 2 days before implant removal in order to initiate luteolysis. Follicular development was monitored by transrectal ultrasonography from the time of PG administration until $\sim 12 \mathrm{~h}$ before ovariectomy. Animals were allocated to one of five groups according to the time of ovariectomy, as follows: day 0 (follicular phase, pre-LH surge; $n=5$ ), day 1 (follicular phase, post-LH surge, pre-ovulation; $n=6$ ), day 3 (post-ovulation, selection phase; $n=6$ ), day 6 (post-ovulation, dominance phase; $n=5$ ) or day 12 (post ovulation, atretic phase; $n=6$ ).

Excised ovaries were placed in ice-cold PBS, and the number of follicles $\geq 5 \mathrm{~mm}$ and their diameters were recorded before bFF was aspirated from each follicle. The bFF samples were aliquotted and stored at $-80{ }^{\circ} \mathrm{C}$ until analysis. For the present study, follicles from each pair of ovaries were classified as the dominant follicle (DF) (the largest or morphologically DF), first subordinate follicle (SF1) (the second largest or SF1) or SF2p (bFF pooled from all of the remaining $\mathrm{SFs} \geq 5 \mathrm{~mm}$ ). In addition, bFF concentrations of $E_{2}$ and $P_{4}$ were used to classify follicles as either oestrogen active $\left(E A ; E_{2}: P_{4}\right.$ ratio $\left.>1\right)$ or oestrogen inactive $\left(\mathrm{El} ; \mathrm{E}_{2}: \mathrm{P}_{4}\right.$ ratio $\left.<1\right)$ (Ireland \& Roche 1982).

\section{Hormone immunoassays}

Concentrations of androstenedione in theca cell-conditioned media were determined by RIA (Glister et al. 2005). The detection limit of the assay was $50 \mathrm{pg} / \mathrm{ml}$, and the intra- and inter-assay coefficient of variations (CV) were 8 and $10 \%$ respectively. 'Total' (i.e. free+activin-bound) FST levels in bFF samples and chromatographic fractions were determined by 


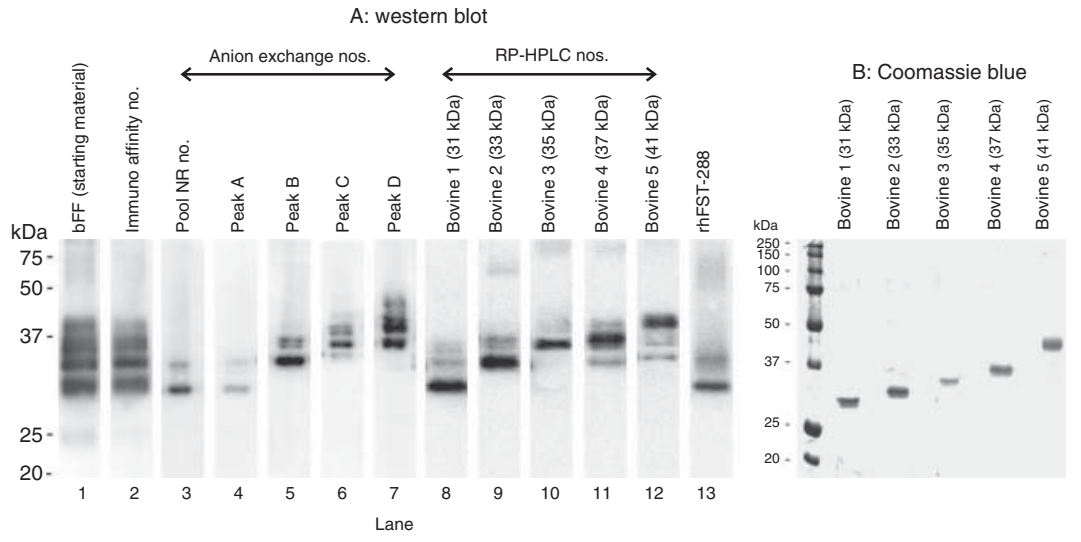

Figure 1 SDS-PAGE/western blotting analysis of chromatographic fractions generated during the purification of FST isoforms from bovine follicular fluid (bFF). Samples were electrophoresed under non-reducing conditions using $12.5 \%$ acrylamide gels. (A) The proteins were transferred to nitrocellulose membrane and immunostained with FST antibody. (B) The gel was directly stained for total protein using Coomassie blue. two-site ELISA (Tannetta et al. 1998). Values are expressed in terms of an rhFST preparation provided by Dr A Parlow (NHPP, Torrance, CA, USA). Assay sensitivity was 100 pg/ml, and intraand inter-assay $C V$ were 7 and $9 \%$ respectively. 'Total' activin A concentrations in bFF were measured by two-site ELISA (Knight et al. 1996). rh activin A (NIBSC, Potters Bar, Hertfordshire, UK) was used as a standard, and the assay sensitivity was $100 \mathrm{pg} / \mathrm{ml}$. Intra- and inter-assay CV were 4 and $7 \%$ respectively. 'Total' activin $\mathrm{AB}$ concentrations were measured by two-site ELISA (Evans et al. 1997). The assay was calibrated using purified preparation of porcine activin $\mathrm{AB}$ (gift from $\mathrm{H}$ Sugino) and had a sensitivity of $200 \mathrm{pg} / \mathrm{ml}$. Intra- and inter-plate CV were 5 and $8 \%$ respectively. Activin $B$ concentrations were evaluated using a more recently developed two-site ELISA (Ludlow et al. 2009). The assay was calibrated using rh activin B (R\&D Systems), and the sensitivity in our laboratory was about $100 \mathrm{pg} / \mathrm{ml}$. Intra- and inter-plate CV were 9 and $12 \%$ respectively.

\section{Statistical analysis}

Data from in vitro bioassays and Biacore experiments that compared the different FST isoforms that we isolated were evaluated using ANOVA and post hoc Fisher's protected least significant difference (PLSD) test. One-way and two-way ANOVAs of log-transformed data were used to evaluate between-group differences in bFF levels of activin A, activin $A B$, 'total' FST and the proportion of 'total' FST represented by each of the six individual isoforms detected. Where indicated, post hoc Fisher's PLSD test was subsequently used to make individual pairwise comparisons. Linear correlation analyses were also used to examine the relationship between the variables among the entire sample set. Unless stated otherwise, values are presented as arithmetic means \pm s.E.M.

\section{Results}

\section{Chromatographic purification of bovine ovarian FST isoforms}

Figure 1 (lane 1) shows the presence of six different bands of FST immunoreactivity in pooled bFF (starting material). These bands had apparent molecular weights $\left(M_{r}\right)$ that ranged from 31 to $65 \mathrm{kDa}$. When FST was purified by affinity chromatography on an immobilised FST-MAb column, the eluate contained five $M_{r}$ forms that ranged from 31 to $41 \mathrm{kDa}$ (Fig. 1, lane 2). When this material was applied to an anion exchange column (Mono P), five major regions of FST immunoreactivity (Fig. 1, lanes 3-7) were identified (by FST ELISA and western blotting) that corresponded to peaks A, B, C and $D$ plus the NR fraction that passed straight through the column (Fig. 2). Each of these five anion exchange fractions was further fractionated by reversed-phase HPLC to generate the final five highly purified FST isoforms (1-5) that are shown in Fig. 1A (lanes 8-12). The purity of each isoform was judged to be $\geq 74 \%$ based on densitometric analysis of FST immunoblots and $\geq 79 \%$ based on densitometric analysis of Coomassie bluestained gels (see Fig. 1B, Table 1). The purified FST

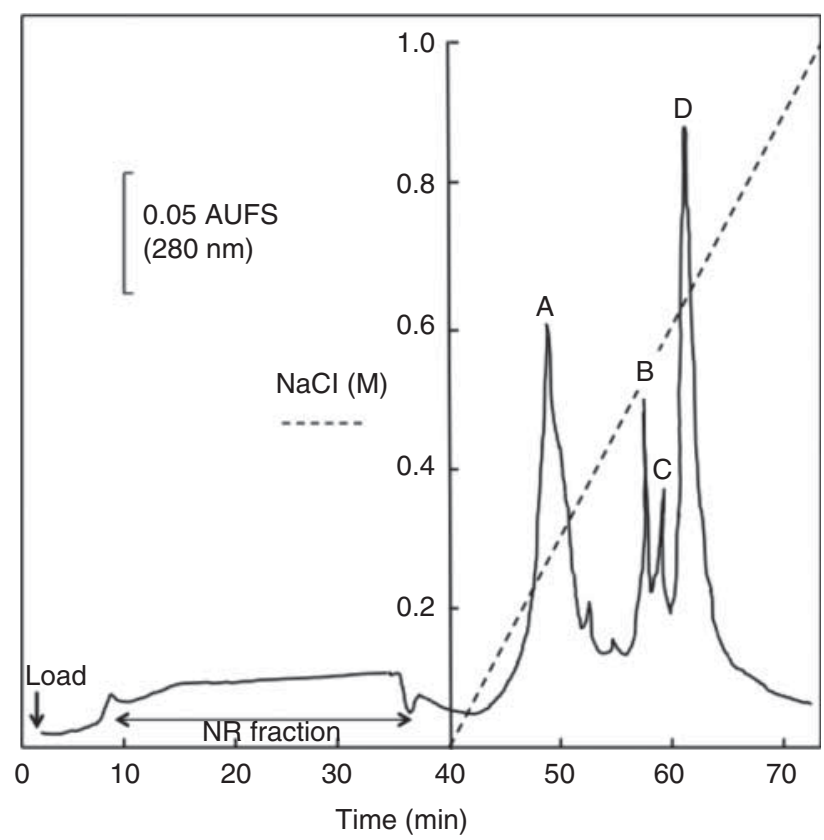

Figure 2 Elution profile (absorbance at $280 \mathrm{~nm}$ ) for the anion exchange FPLC step after applying the highly enriched fraction from the FST immunoaffinity column. 
Table 1 Estimates of the molecular weight and relative purity of the five follistatin isoforms isolated from bovine follicular fluid.

\begin{tabular}{|c|c|c|c|c|c|}
\hline $\begin{array}{l}\text { Purified follistatin } \\
\text { isoform }\end{array}$ & $\begin{array}{c}\text { Apparent molecular } \\
\text { weight }(\mathrm{kDa})\end{array}$ & $\begin{array}{c}\text { Total yield (based on } \\
\left.\mathbf{A}_{\mathbf{2 8 0}} \mathbf{n m}\right)(\mu \mathrm{g})\end{array}$ & $\begin{array}{l}\text { Purity (western } \\
\text { blot) }(\%)\end{array}$ & $\begin{array}{l}\text { Purity (Coomassie- } \\
\text { stained gel) }(\%)\end{array}$ & $\begin{array}{l}\text { Purity (follistatin } \\
\text { ELISA) }(\%)\end{array}$ \\
\hline Bovine 1 & 31 & 93 & 83 & 92 & 93 \\
\hline Bovine 2 & 33 & 53 & 75 & 82 & 85 \\
\hline Bovine 3 & 35 & 55 & 85 & 79 & 79 \\
\hline Bovine 4 & 37 & 12 & 74 & 88 & $\sim 100$ \\
\hline Bovine 5 & 41 & 19 & 75 & 82 & 95 \\
\hline
\end{tabular}

preparations represent 8810 - to 11475 -fold purification factors, and the final combined yield was $17.7 \%$ (206 $\mu \mathrm{g}$ FST total; $12-86 \mu$ of each isoform) from $200 \mathrm{ml}$ of bFF starting material (see Table 2). The amount of each FST isoform purified was quantified by a combination of ELISA (calibrated using rhFST-288), u.v. absorbance $(280 \mathrm{~nm})$ and densitometric quantification of western blots with a calibration curve generated by running known amounts of rhFST-288 alongside the purified forms (see Table 3). Relative to the rhFST-288 standard $(100 \%)$, cross reactivities of purified bovine isoforms $1-5$ in the ELISA were 93, 86, 80, 103 and 95\% respectively, and each isoform yielded a parallel dilution curve.

\section{Characterisation of purified FST isoforms}

Because potential Asn-linked glycosylation sites are known to exist in FST proteins (Sugino et al. 1993), the purified proteins were treated with a mixture of deglycosylation enzymes that included PNGase F, which cleaves all asparagine-linked oligosaccharides, to ascertain whether the various forms were glycosylated variants of the core FST proteins. The multi-glycosylated protein fetuin, which was included in the deglycosylation kit, served as a positive control; upon deglycosylation, it ran as a smaller form on SDS-PAGE (Fig. 3, lanes $1-2$ ). When enzyme-treated FST isoforms were electrophoresed under non-reducing conditions, nos 1, 2 and 3 did not undergo a mobility shift, running at 31,33 and $35 \mathrm{kDa}$ respectively (Fig. 3, lanes 3-8). Upon deglycosylation, no. 5 underwent a mobility shift from 41 to 35 kDa (Fig. 3, lanes 9-10). Unfortunately, insufficient amounts of no. 4 (apparent $M_{r} 37 \mathrm{kDa}$ ) were available for inclusion in the deglycosylation experiment. Based on the size at which they ran on SDS-PAGE, we deduced from these observations that no. 1 is a non-glycosylated variant of core protein 288, no. 2 is a non-glycosylated variant of core protein 303, no. 3 is a non-glycosylated variant of core protein 315, and no. 5 appears to be the glycosylated variant of core protein 315 .

\section{Biological potencies of purified FST isoforms}

The biological properties of the five purified bovine FST forms, along with rhFST-288, were compared by in vitro theca cell bioassay. As shown in Fig. 4, activin A suppressed $\mathrm{LH}$-induced androstenedione secretion by $\sim 85 \% \quad(P<0.0001)$. Co-treatment of cells with FST dose-dependently reversed the suppressive effect of activin on LH-induced androstenedione secretion. Each FST isoform neutralised activin A bioactivity to a greater or lesser degree, with $\mathrm{ED}_{50}$ values ranging from 1.7- to 4.4-fold molar excess FST over activin ( $\mathrm{ED}_{50}$ data summarised in Table 3). Bovine $1(31 \mathrm{kDa})$ had the same biopotency as rhFST-288 $(31 \mathrm{kDa})$ from a commercial source (R\&D Systems). Conversely, bovines 3

Table 2 Purification table for bovine follistatin isoforms.

\begin{tabular}{|c|c|c|c|c|}
\hline Fraction & Total protein $^{\mathrm{a}}(\mathrm{mg})$ & Follistatin $^{\mathrm{b}}(\mu \mathrm{g})$ & Purification (fold) & Recovery (\%) \\
\hline bFF (start material) & 13000 & 1164 & 1 & 100 \\
\hline Immuno-affinity eluate & 3.28 & 733 & 2497 & 63 \\
\hline \multicolumn{5}{|l|}{ Anion exchange } \\
\hline Non-retained no. & ND & 127.4 & ND & 10.95 \\
\hline Peak A & ND & 24.3 & ND & 2.08 \\
\hline Peak B & ND & 110.9 & ND & 9.53 \\
\hline Peak C & ND & 25.4 & ND & 2.18 \\
\hline Peak D & ND & 115.9 & ND & 9.97 \\
\hline Total & ND & 403.9 & ND & 34.7 \\
\hline \multicolumn{5}{|l|}{ RP-HPLC } \\
\hline Bovine 1 & 0.093 & 86.6 & 10400 & 7.44 \\
\hline Bovine 2 & 0.053 & 45.3 & 9553 & 3.89 \\
\hline Bovine 3 & 0.055 & 43.4 & 8810 & 3.73 \\
\hline Bovine 4 & 0.012 & 12.3 & 11475 & 1.06 \\
\hline Bovine 5 & 0.019 & 18.0 & 10721 & 1.55 \\
\hline Total $(1-5)$ & 0.232 & 205.6 & 10191 & 17.7 \\
\hline
\end{tabular}

$\mathrm{ND}$, not determined.

${ }^{\mathrm{a}}$ Based on absorbance at $280 \mathrm{~nm}$. ${ }^{\mathrm{b}}$ Based on follistatin ELISA. 
Table 3 Comparison of the biological potencies of the five isoforms of follistatin isolated from bovine follicular fluid with that of human recombinant follistatin 288 .

\begin{tabular}{lccc}
\hline $\begin{array}{l}\text { Follistatin } \\
\text { isoform }\end{array}$ & $\begin{array}{c}\text { Molecular } \\
\text { weight } \\
(\mathrm{kDa})\end{array}$ & $\begin{array}{c}\text { Mean IC } \mathbf{5 0} \text { in } \\
\text { bioassay } \\
\text { (FST: activin ratio) }\end{array}$ & $\begin{array}{c}\text { Relative } \\
\text { biopotency (\%) }\end{array}$ \\
\hline rhFST-288 & 31 & 1.7 & 100 \\
Bovine 1 & 31 & 1.7 & 100 \\
Bovine 2 & 33 & 2.2 & 77 \\
Bovine 3 & 35 & 4.4 & 39 \\
Bovine 4 & 37 & 1.9 & 89 \\
Bovine 5 & 41 & 3.2 & 53 \\
\hline
\end{tabular}

and 5 (35 and $41 \mathrm{kDa}$ respectively) had the lowest biopotencies of all the forms tested (39 and 53\% relative to rhFST-288 at $100 \%$ ). In the absence of activin treatment (Fig. 4B), none of the FST forms tested had any significant effect on thecal cell androstenedione production, which was consistent with the lack of endogenous activin production by those cells.

\section{Activin binding properties of purified FST isoforms}

To investigate whether the differences observed between FST isoforms in neutralising activin bioactivity reflected different binding affinities of these FST forms for activin, the dissociation constant (KD) of each form for immobilised activin A was quantified using Biacore (Table 4). The KD was significantly greater for each of the larger FST isoforms $(33,35,37$ and $41 \mathrm{kDa})$ than it was for the smallest isoform no. 1 (31 kDa) and rhFST-288, which indicates lower affinity binding. The 35 and $41 \mathrm{kDa}$ isoforms formed the least stable complexes with activin A; $K D$ values were some 20-fold higher $(\sim 33 \mathrm{nM})$ for those isoforms than they were for the $31 \mathrm{kDa}$ isoform (1.6 $\mathrm{nM})$.

\section{Heparan sulphate binding properties of purified FST isoforms}

The differential ability of FST isoforms to bind to cellsurface HSPs has been implicated as a method whereby FST modulates the activity of activin in different extracellular compartments. We therefore used Biacore to examine the ability of our purified bovine FST forms to bind to immobilised HSP. As shown in Table 4, isoform no. $1(32 \mathrm{kDa})$ and rhFST-288 of the same molecular weight both bound to HSP with similar KD values $(\sim 3 \mathrm{nM})$. However, no quantifiable binding of FST isoform nos. 2, 3, 4 or 5 to immobilised HSP was observed.

\section{Comparison of biological potencies and FST binding properties of activins $A, A B$ and $B$}

In terms of their ability to suppress androstenedione secretion in the theca cell bioassay (Table 5), activin A was about twofold more potent than activin $A B$, whereas activin B did not elicit a response at the maximum concentration tested $(50 \mathrm{ng} / \mathrm{ml})$. Biacore analysis showed that activin $A B$ and activin $B$ bound to immobilised rhFST-288 with approximately twofold higher affinity than activin A did (Table 5). There were insufficient amounts of purified bovine FST isoforms available to carry out a systematic evaluation of their binding affinities for the three different rh activin isoforms.

\section{Analysis of FST and activin isoforms in bFF samples from oestrous cycle-synchronised heifers}

Circulating gonadotrophin ( $\mathrm{LH}, \mathrm{FSH})$ and steroid hormone $\left(\mathrm{E}_{2}, \mathrm{P}_{4}\right)$ profiles as well as detailed information on ovarian ultrasonography and intrafollicular $\mathrm{E}_{2}, \mathrm{P}_{4}$ and inhibin concentrations in these heifers have been documented in a previous report (Sunderland et al. 1996); therefore, only new information pertaining to the analysis of FST and activin isoforms in bFF is presented in the present paper (Fig. 5). Preliminary analysis of a subset of pooled bFF samples showed that activin B concentrations $(214 \pm 25 \mathrm{ng} / \mathrm{ml})$ were substantially ( $\sim 20$-fold) lower than activin A $(4333 \pm 379 \mathrm{ng} / \mathrm{ml})$ and approximately sixfold lower than activin AB $(1259 \pm 71 \mathrm{ng} / \mathrm{ml})$ concentrations. Given the limited bFF sample volumes available, it was not feasible to determine activin B concentrations in the present sample set.

Overall, follicle diameter was positively correlated with $\mathrm{E}_{2}: \mathrm{P}_{4}$ ratio $(r=0.56 ; P<0.0001)$ and negatively correlated with activin $\mathrm{A}(r=-0.34 ; P=0.003)$, activin $\mathrm{AB}(r=-0.51 ; P<0.0001)$ and 'total' FST as measured by ELISA $(r=-0.70 ; P<0.0001)$. Using SDS-PAGE/ western blotting five to six different FST isoforms were detected in individual bFF samples (apparent Mr: 65, 41, $37,35,33$ and $31 \mathrm{kDa}$ ) that represented, on average, 6,

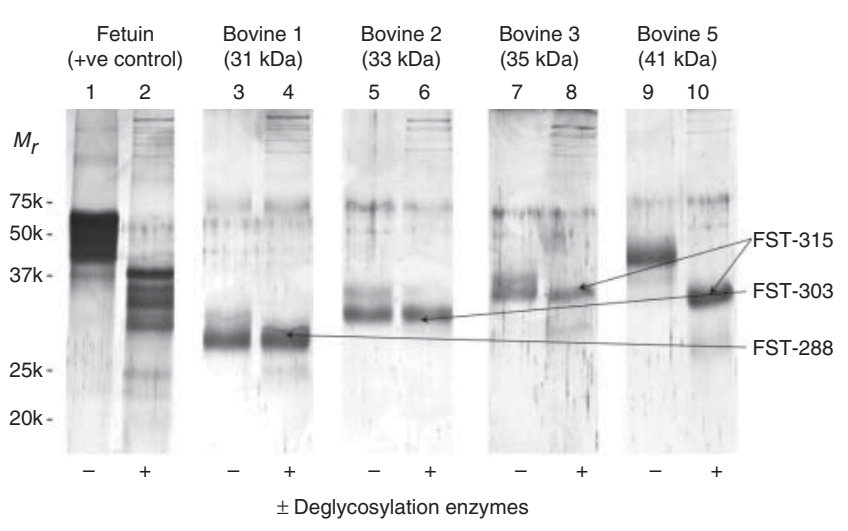

Figure 3 SDS-PAGE analysis of four purified bovine FST isoforms before $(-)$ and after $(+)$ enzymatic deglycosylation. Samples were electrophoresed under non-reducing conditions using $12.5 \%$ acrylamide gels, and total protein was detected by silver staining. Lanes $1-2$ show the behaviour of the control protein (fetuin) that was supplied with the deglycosylation kit. 


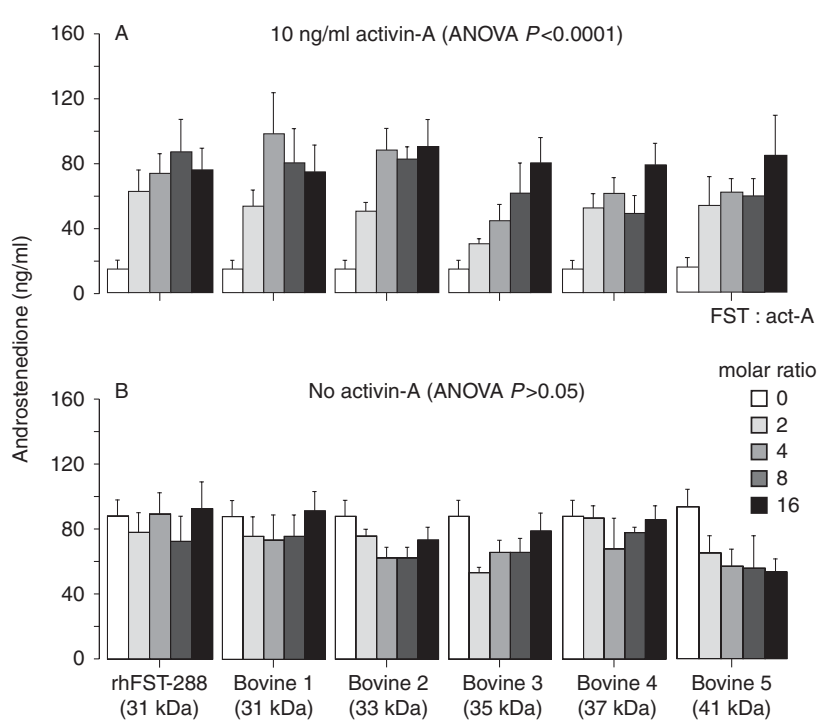

Figure 4 (A) Comparison of the biopotencies of the five purified isoforms of bovine FST and rhFST-288 in reversing the activin A-induced suppression of androstenedione secretion by bovine theca cells in vitro. (B) None of the FST preparations affected 'basal' androstenedione secretion by cells that were cultured in the absence of activin A. Act-A, activin A.

$13,24,26,13$ and $17 \%$ respectively of the total FST (Fig. 6). Follicle diameter was positively correlated with the relative abundance of the $41 \mathrm{kDa} \quad(r=0.59$; $P<0.0001)$ and $35 \mathrm{kDa}(r=0.29 ; P=0.014)$ FST isoforms but negatively correlated with the relative abundance of the smaller $33 \mathrm{kDa} \quad(r=-0.56$; $P<0.0001)$ and $31 \mathrm{kDa}(r=-0.41 ; P<0.001)$ FST isoforms. There was a particularly marked effect of follicle status on the relative abundance of the $33 \mathrm{kDa}$ isoform, which showed up to a threefold difference $(P<0.0001)$ between DF and SF2p follicles.

Two-way ANOVA revealed a significant effect of cycle day $(P<0.05)$ and follicle status $(P<0.01)$ (i.e. DF, SF1 or $S F 2 p$ ) on follicle diameter, $E_{2}: P_{4}$ ratio, activin $A$, activin $A B$ and 'total' FST concentrations (Fig. 5). Furthermore, the FST concentration was much lower in DF than it was in SF1 or SF2p $(P<0.05)$. During growth and the selection of the 'first-wave' follicles in the early luteal phase (i.e. days 3-6), 'total' FST, activin $A$ and activin $A B$ concentrations decreased in DF $(P<0.05)$ but were maintained or increased in SF1 and SF2p. During subsequent atresia of DF (i.e. days 6-12), 'total' FST and activin $A B$ remained lower in DF than they did in SF1 and SF2p (Fig. 5). Two-way ANOVA revealed a significant $(P<0.05)$ effect of follicle status on relative abundance of the $41,37,35,33$ and $31 \mathrm{kDa}$ FST isoforms and an effect of cycle day on the relative abundance of the $65 \mathrm{kDa}$ FST isoform (Fig. 6).

In 'follicular phase' samples (Fig. 5), follicle status significantly affected total FST and activin $A B$ concentrations, activin:FST ratio and $\mathrm{E}_{2}: \mathrm{P}_{4}$ ratio. FST concentration was much lower in DF than it was in SF1 or SF2p. There was also a significant effect of cycle day (i.e. pre- vs post-LH surge) on activin $A$, activin $A B$ and FST levels. Follicle status, but not cycle day, also affected the relative abundance of the 41, 33 and $31 \mathrm{kDa}$ FST isoforms (Fig. 6).

\section{Discussion}

It has been well established that FST can selectively attenuate signalling by activins and, to a lesser degree, other ligands that belong to the TGF $\beta$ superfamily (e.g. BMP2, BMP4, BMP7, BMP15, GDF9 and myostatin/GDF8) by forming a stable inactive complex with the ligand in the extracellular compartment, which thereby blocks binding to signalling receptors (Sugino et al. 1993, Nakamura et al. 1997, Phillips \& de Kretser 1998, Chang 2008). However, the existence of multiple isoforms of FST in biological fluids such as ovarian FF and serum (Robertson 1992, Sugino et al. 1993, Nakamura et al. 1997, Schneyer et al. 1997, Glister et al. 2006) is indicative of a more complex scenario, the potential significance of which has yet to be fully resolved. FST isoforms differ in their ability to bind to proteoglycans on the cell surface and extracellular matrix; the shorter, carboxy-terminal truncated form (FST-288) shows a much higher affinity for HSP than the long isoform (FST-315) does. This reflects the ability of the carboxy-terminal domain of FST-315 to mask the HSP binding region found within the FS1 domain (Keutmann et al. 2004, Hedger \& de Kretser 2013). Activin binding activity involves the amino terminal domains FS1 and FS2 (Keutmann et al. 2004, Chang 2008). Differences in the propensity of FST isoforms to bind to cell surface proteoglycans is indicative of differential roles in controlling activin distribution and bioavailability at local and/or distant target tissue levels.

In view of the substantive evidence to implicate the inhibin-activin-FST system in ovarian follicle development, in the present study, we devised an effective chromatographic scheme to purify five native isoforms of FST from bovine ovaries (overall FST yield 17.7\%; $\sim 10000$-fold purification factor), which thus permitted

Table 4 Comparison of activin A and heparin sulphate proteoglycan (HSP) binding properties of five isoforms of follistatin isolated from bovine follicular fluid.

\begin{tabular}{lccc}
\hline $\begin{array}{l}\text { Follistatin } \\
\text { isoform }\end{array}$ & $\begin{array}{c}\text { Molecular } \\
\text { weight }(\mathrm{kDa})\end{array}$ & $\begin{array}{c}\text { KD (activin A) } \\
(\mathrm{nM})\end{array}$ & KD (HSP) $(\mathrm{nM})$ \\
\hline rhFST-288 & 31 & $1.8 \pm 0.61^{\mathrm{ab}}$ & $3.93 \pm 0.57^{\mathrm{a}}$ \\
Bovine 1 & 31 & $1.6 \pm 0.16^{\mathrm{a}}$ & $2.94 \pm 1.36^{\mathrm{a}}$ \\
Bovine 2 & 33 & $2.9 \pm 0.30^{\mathrm{ab}}$ & $\mathrm{ND}$ \\
Bovine 3 & 35 & $33.2 \pm 13.9^{\mathrm{c}}$ & $\mathrm{ND}$ \\
Bovine 4 & 37 & $4.4 \pm 1.48^{\mathrm{b}}$ & $\mathrm{ND}$ \\
Bovine 5 & 41 & $34.3 \pm 4.14^{\mathrm{c}}$ & $\mathrm{ND}$ \\
$P$ value (ANOVA) & & $<0.001$ & 0.24 \\
\hline
\end{tabular}

$\mathrm{ND}$, not determined because binding was too low to quantify. Within each column, means without a common superscript letter are significantly different $(P<0.05)$. 
Table 5 Comparison of follistatin ${ }^{\text {a }}$ binding properties and biological potencies (bovine theca cell bioassay) of three recombinant human activin isoforms.

\begin{tabular}{lcc}
\hline Activin isoform & KD $(\mathbf{F S T})(\mathrm{nM})$ & Bioassay $\mathbf{I C}_{\mathbf{5 0}}(\mathrm{ng} / \mathrm{ml})$ \\
\hline Activin A & $0.36 \pm 0.02^{\mathrm{b}}$ & $7.3 \pm 2.7^{\mathrm{b}}$ \\
Activin AB & $0.15 \pm 0.01^{\mathrm{c}}$ & $14.7 \pm 7.8^{\mathrm{b}}$ \\
Activin B & $0.14 \pm 0.01^{\mathrm{c}}$ & $>50^{\mathrm{c}}(\mathrm{NR})$ \\
$P$ value (ANOVA) & $<0.01$ & $<0.01$ \\
\hline
\end{tabular}

$\mathrm{NR}$, no detectable response at $50 \mathrm{ng} / \mathrm{ml}$. Within each column, means without a common superscript letter are significantly different $(P<0.05)$. a rhFST-288.

a comparison of their biological activities and binding affinities for activin A and HSP. We showed that all five FST isoforms were capable of blocking the suppressive effect of activin on androgen secretion by bovine theca cells. The smallest isoform (bovine 1, $31 \mathrm{kDa}$, which was deduced to be the non-glycosylated, carboxy-terminal truncated form, FST-288) represented about $17 \%$ of the total FST in bFF. It was also the most biopotent and was equipotent with rhFST-288 (31 kDa) obtained from a commercial source. Moreover, it exhibited KD values for binding to activin A and HSP that were very similar to those for rhFST-288. In contrast, two of the larger isoforms that we isolated (35 and $41 \mathrm{kDa}$ ) showed reduced biopotency (39 and 53\% respectively) as well as significantly lower affinity for activin A and undetectable binding to HSP. On the basis of their mobility on SDSPAGE before and after enzymatic deglycosylation, it was deduced that the $35 \mathrm{kDa}$ isoform (bovine 3) is nonglycosylated FST-315, whereas the $41 \mathrm{kDa}$ isoform (bovine 5) is its glycosylated counterpart. Respectively, these FST isoforms represented 26 and $13 \%$ of the total FST in bFF. The other two isoforms we purified, bovine 2 $(33 \mathrm{kDa})$ and $4(37 \mathrm{kDa})$ had relative biopotencies that were not significantly different from FST-288 (77 and $89 \%$ respectively). The affinity of the $37 \mathrm{kDa}$ isoform for activin $\mathrm{A}$ was approximately threefold less than that of FST-288, and neither the 33 or $37 \mathrm{kDa}$ isoform showed detectable binding to HSP. The $33 \mathrm{kDa}$ isoform was deduced to be a non-glycosylated variant of FST-303 core protein, seeing as no mobility shift occurred upon deglycosylation. The $33 \mathrm{kDa}$ form represented on average $13 \%$ of the total FST in bFF, although, as discussed later in the present paper, it showed a substantial follicle status-dependent variation in vivo (6-21\% of the total FST). The chromatographic yield of the $37 \mathrm{kDa}$ FST isoform was low (only $12 \mu \mathrm{g}$ recovered), and there was insufficient material to further characterise it by deglycosylation mobility shift analysis. However, on the basis of the previous characterisation of porcine FST isoforms (Sugino et al. 1993), it was considered to likely be a glycosylated form of FS-303.

The native bovine FST isoforms we isolated differed both in their ability to neutralise activin A bioactivity in vitro and in their binding affinity for activin A. This observation contrasts with an early report (Sugino et al. 1993) that suggested that different FST isoforms purified from porcine FF displayed very similar activin binding activities. However, in that study, activin binding was estimated using a polyethyleneglycol precipitation method with ${ }^{125}$ I-labelled activin $A$ as opposed to the direct binding of FST to unlabelled activin A immobilised on a Biacore sensor chip that was used in the present study. Another study that employed the Biacore approach (Hashimoto et al. 2000) reported that rhFST-288 bound activin A with an affinity that was an order of magnitude higher than rhFST-315, a finding that is in agreement with the present comparison of native bovine FST isoforms.

To our knowledge, the present report is the first to compare both the bioactivities and FST binding properties of the three activin isoforms. In terms of their relative bioactivity, it has been reported previously that activin B is much less potent that activin $\mathrm{A}$ in various in vitro bioassays (Sugino et al. 1997, Schneyer et al. 2003), a finding that is in agreement with the present study, which used a bovine theca cell bioassay. Using immobilised rhFST-288, we also found that the binding affinities for
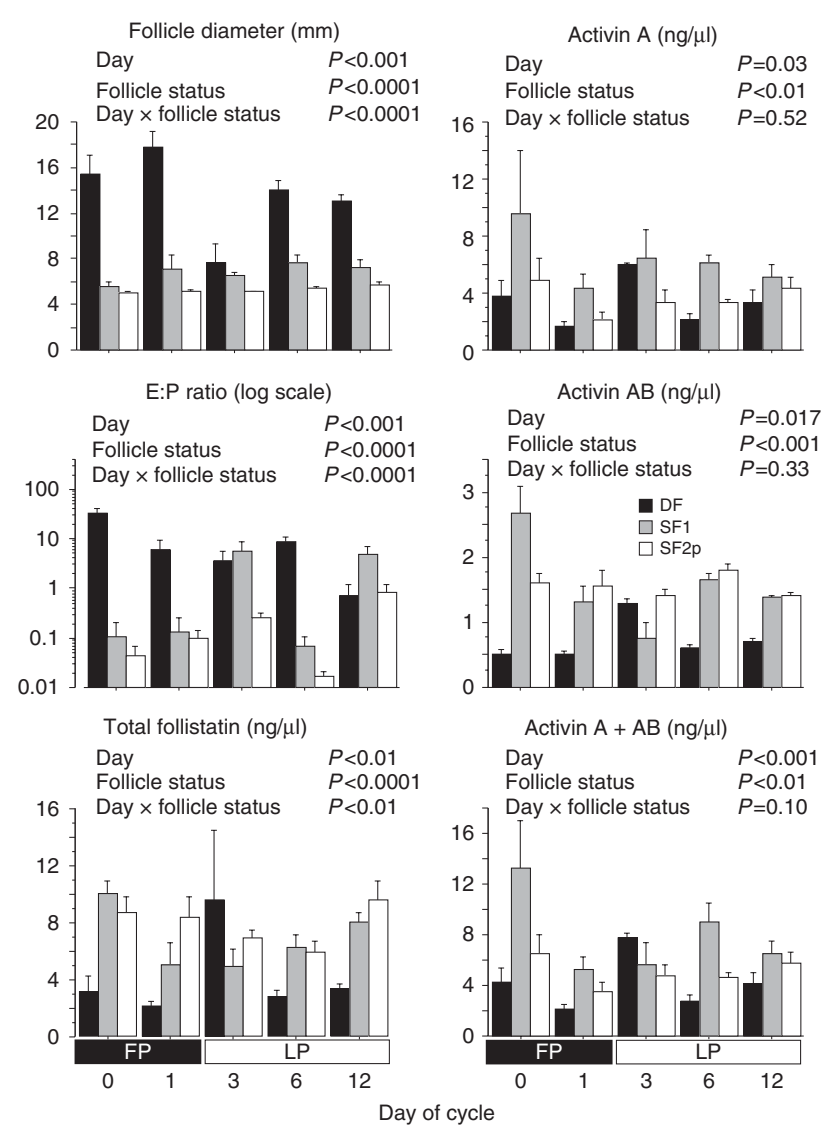

Figure 5 Changes in follicle diameter and $E_{2}: P_{4}$ ratio, activin $A$, activin $A B$, combined activin $A / A B$ and total FST concentrations in follicular fluid obtained from cattle $(n=28)$ that were ovariectomised at five time points during a synchronised oestrous cycle. The horizontal bar beneath the $x$-axis distinguishes the follicular phase (FP) from the luteal phase (LP). Values are presented as means \pm S.E.M., and two-way ANOVA results are indicated on each panel. 


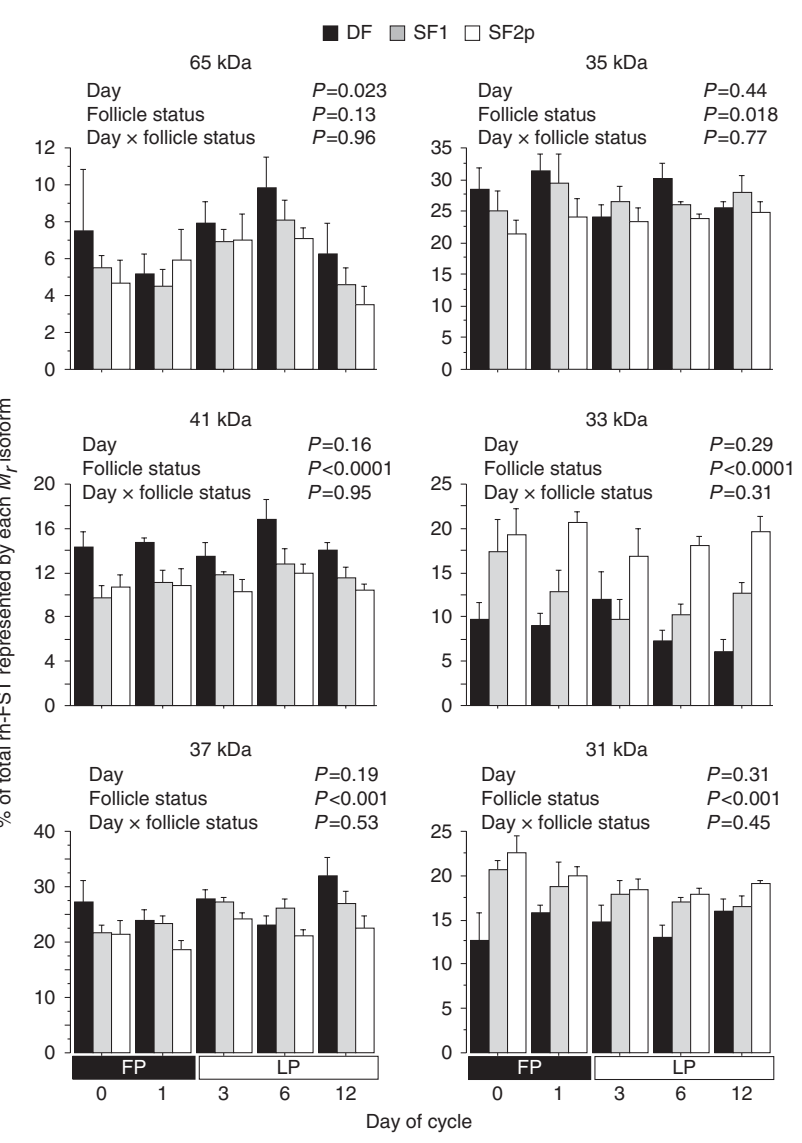

Figure 6 Changes in the relative abundance (\%) of six different $M_{r}$ isoforms of FST in follicular fluid obtained from cattle $(n=28)$ that were ovariectomised at five time points during a synchronised oestrous cycle. The horizontal bar beneath the $x$-axis distinguishes the follicular phase (FP) from the luteal phase (LP). Values are presented as means \pm S.E.M. and two-way ANOVA results are indicated on each panel.

activin $A B$ and activin $B$ were significantly higher than they were for activin $A$, and we suggest that this could contribute to the higher biopotency of activin A. However, it was reported (Schneyer et al. 2003) that activin B bound to rhFST-288 with a lower affinity than activin A, as measured by a radioligand binding assay. This is in disagreement with the present findings, which were based on the Biacore technique. Regardless of this discrepancy, the present study shows that levels of activin $B$ in bFF are much lower than those of activin $A B$, which, in turn, are lower than those of activin $A$. Collectively, these observations suggest that activin B plays (a) minimal physiological role(s) in bovine antral stage follicles.

Evidently, the present study is also the first to compare the bioactivities of multiple native FST isoforms using a homologous (i.e. same-species) ovarian bioassay. Many studies have used the FST-dependent inhibition of FSH release from rat anterior pituitary cells as a heterologous bioassay for purified porcine or bovine FST preparations (Robertson et al. 1987, Sugino et al. 1993, 1997), because it provides the possibility that species differences could affect the relative responses observed. In fact, bovine isoform no. 1 , which is evidently unglycosylated core protein FST-288, behaved identically to rhFS-288 in the present bovine theca cell bioassay and had the highest biopotency of the five FST isoforms that we purified. Similarly, the activin binding affinity of isoform no. 1 was not significantly different from rhFS-288 and was also the highest of the five isoforms. Moreover, of the different FST preparations tested, only rhFST-288 and bovine isoform no. 1 had the ability to bind to HSP; both exhibited a similar KD value of 3-4 $\mathrm{nM}$, which is close to the value that was reported by Sugino et al. (1997) for the binding of porcine FST-288 to granulosa cell membranes (KD $2 \mathrm{nM}$ ). These observations support the notion that FST-288 is the most effective of all of the isoforms at neutralising activin A activity, at least in the present in vitro bioassay. This neutralisation can arise by a two-step mechanism: not only does it bind to activin A with the greatest affinity and thereby block its interaction with activin signalling receptors, but it also has the greatest propensity to bind to cell surface-associated HSPs and to thereby become concentrated on the cell surface to provide an even more effective 'barrier' for preventing activin association with its signalling receptors. In addition, it has been shown that activin-FST complexes that are bound to HSPs on the cell surface are endocytosed, which leads to their subsequent lysosomal degradation (Hashimoto et al. 1997, Sugino et al. 1997). The KD value we observed for FST-288-activin A binding was of the same order of magnitude (low nM range) as that for FST-288-HSP binding, which indicates stable complex formation in both cases. In further work, it would be of interest to use the Biacore technique to examine the binding kinetics of ternary complex formation/dissociation (HSP-FST-activin) in an attempt to model likely interactions at or near the cell surface in vivo.

We deduced that purified bovine isoforms nos 3 and 5 are non-glycosylated and glycosylated variants of core protein FST-315 respectively. They showed the lowest activin biopotencies of the five isoforms purified: they were up to $60 \%$ less effective at neutralising activin in bioassay than isoform no. 1 (FST-288) was. Moreover, their affinity for activin A was an order of magnitude less than that of isoform no. 1/FST-288. Although this finding conflicts with a previous report that suggested that different isoforms of porcine FST show similar activin binding affinities (Sugino et al. 1993), the present finding is in agreement with a later study that compared rhFST-288 and FST-315 activin binding affinities (Hashimoto et al. 2000). The explanation for this discrepancy is not known, but consistent with earlier findings for porcine (Sugino et al. 1993, 1997), the larger isoforms of bovine FST that we isolated displayed much lower (non-quantifiable) binding to HSP. 
Having examined the biological activities and activin and HSP binding properties of the different naturally occurring FST isoforms purified from bovine ovaries, we considered whether their relative intrafollicular expression levels vary during bovine follicle development in vivo. To address this question, we used a quantitative immunoblotting approach to analyse individual bFF samples harvested from the follicles of oestrous cycle-synchronised cattle that had been ovariectomised at five key stages of follicle 'wave' development (Sunderland et al. 1996). Additionally, we used a panel of specific two-site immunoassays to quantify 'total' FST, activin A and activin AB concentrations in the same samples; attempts to quantify activin $B$ in individual samples using a new immunoassay (Ludlow et al. 2009) were unsuccessful because of the much lower concentration that was present and the insufficient sample volumes that were available. Concentrations of activin A were around threefold higher than those of activin $A B$ and were estimated to be at least 20-fold higher than activin $B$ levels, which indicated a minimal physiological role for activin $B$ in the bovine antral follicle.

Although the interpretation of the resultant data set is complex because of the number of different analytes, time points and follicle status categories involved, the findings are broadly consistent with those of an earlier study that involved the analysis of size-ranked follicles from the ovaries of randomly cycling cattle obtained from an abattoir (Glister et al. 2006). In particular, total FST levels in bFF were inversely related to follicle diameters and $\mathrm{E}_{2}: \mathrm{P}_{4}$ ratios in both studies. Likewise, the average proportion of total FST represented by each isoform was very similar in both studies. FST-288 core protein represented about $17 \%$ of the total FST, whereas glycosylated/non-glycosylated forms of the carboxyterminal extended core proteins FST-303 and FST-315 represented $13 / 24$ and $26 / 13 \%$ respectively. The relatively low abundance of FST-288 that was present in bFF was still much higher than the estimate of $1 \%$ that has been reported for porcine FF (Inouye et al. 1991), which suggests a pronounced species variation. The low abundance of FST-288 present in FF most likely reflects its high affinity for HSP, which results in its adhesion to the plasma membrane of the granulosa cells that line the follicular antrum and cumulus cells surrounding the oocyte. By contrast, FST-303 and FST-315 tend to remain in the liquid phase and are likely to diffuse further from their site of secretion (granulosa cells) to sequester activins and other TGF $\beta$ family ligands that arise from other intra- or extra-ovarian sources and perhaps to act as 'activin reservoirs'. Interestingly, although each FST isoform showed some variation in relation to follicle status and stage of cycle, the $33 \mathrm{kDa}$ isoform (deduced to be FST-303 core protein) showed the greatest difference in relative abundance between the dominant and SFs; it was up to threefold higher in the latter. Although the explanation for and/or physiological significance of this intriguing observation remains obscure, it has been speculated that DFs may show decreased expression of a specific protease that cleaves FST-315 into FST-303 (Welt et al. 2002). Consistent with this suggestion, the abundance of the 41 and $35 \mathrm{kDa}$ isoforms (glycosylated/ non-glycosylated FST-315) tended to show the reverse pattern to FST-303 and were highest in DFs. The nature of the $65 \mathrm{kDa}$ band, which represented about $6 \%$ of immunoreactive FST as detected by immunoblotting in bFF, remains unknown because it was not one of the isoforms that was purified in the present study.

Regarding the physiological interpretation of these data, on days 0,1 and 6 of the cycle (see Fig. 5) the 'selected' healthy DF was clearly distinguished from atretic SFs that were smaller and had lower $\mathrm{E}_{2}: \mathrm{P}_{4}$ ratios but higher total FST (and 33 and $31 \mathrm{kDa}$ FST forms), activin $A$ and activin $A B$. These findings imply that high FST and activin levels may hinder growth and the production of SFs, which is critical for the onset of follicle dominance. This idea is supported by the change in FST and activin levels from day 3 (before selection) to day 6 (when DF was present); during this time, levels of total FST (and 33 and $37 \mathrm{kDa}$ FSH isoforms) and activin $A$ and activin $A B$ decreased as the size and $E_{2}: P_{4}$ ratio increased in the DF. Moreover, on day 3 before the onset of dominance, when DF and SF showed a similar size and $\mathrm{E}_{2}: \mathrm{P}_{4}$ ratio, total FST (and most FST isoforms) and activin levels remained similar between the follicle types. From days 6 to 12, the DF from day 6 became atretic, as was indicated by its greatly reduced $E_{2}: P_{4}$ ratio, but its diameter and total FST, activin $A$ and activin $A B$ levels remained unchanged. However, the relative abundance of multiple FST isoforms (31 and $37 \mathrm{kDa}$ ) increased as the DF from day 6 became atretic, whereas other isoforms $(35,41$ and $65 \mathrm{kDa}$ ) showed a corresponding decrease. The interpretation of this intriguing observation remains unknown, but overall these findings imply that other factors (like inhibin) may be critical for the loss of non-ovulatory DF function.

The expression and secretion of FST by granulosa cells has been shown to be up-regulated by FSH and IGF1 (Klein et al. 1991, Lindsell et al. 1994, Glister et al. 2001, 2003, 2006). However, the relative abundance of different FST isoforms secreted by cultured bovine granulosa cells was found to be very similar under basal and FSH- and IGF1-stimulated conditions (Glister et al. 2006), which makes it difficult to relate the present changes in intrafollicular FST isoform profiles to presumptive changes in $\mathrm{FSH}$ and/or insulin-like growth factor (IGF) action that occur in vivo. The expression of FST by granulosa cells has also been shown to be up-regulated by activin (Michel et al. 1992, Fazzini et al. 2006), but whether activin affects the FST isoform distribution pattern is not known. Intrafollicular levels of activin $A$, activin $A B$ and 'total' FST followed a similar pattern of change in the present study: they were lowest in 
DFs at all of the cycle stages examined, with the exception of day 3 . For the most part, the mass ratio of 'total' activins (i.e. activin $A+A B$ ) to FST levels was maintained around $1: 1$ at all of the follicle stages examined, which is consistent with FST-activin complex formation and at least the partial neutralisation of activin signalling in accordance with the 2:1 binding stochiometry (Shimonaka et al. 1991, Welt et al. 2002, Chang 2008). This apparent lack of saturation of activin's FST binding capacity implies that the bioavailability of other locally expressed TGF $\beta$ ligands that are capable of binding FST, such as BMP2, BMP4, BMP7 and GDF9, may by modulated by intrafollicular FST. An important caveat is that the levels of activins and FST in bFF may provide little indication of their relative concentrations and interactions at or near the cell surface. The challenge remains to devise experimental approaches to address this issue.

In conclusion, we showed that activin A and activin B as well as naturally occurring isoforms of bovine ovarian FST that differ in their biological activity, binding affinities for activin and cell surface proteoglycans display follicle status-dependent differences in their intrafollicular abundance during the bovine oestrous cycle. Given the prominent autocrine/paracrine regulatory roles that activins and other TGF $\beta$ superfamily members are thought to play throughout folliculogenesis, these findings underscore the inherent complexity and multifactorial nature of this system. Further research is needed to delineate the biological significance of the multiple FST isoforms that act as extracellular modulators of signalling by activins and also the other TGF $\beta$ family members that are secreted by the oocyte, granulosa and/or theca cells.

\section{Declaration of interest}

The authors declare that there is no conflict of interest that could be perceived as prejudicing the impartiality of the research reported.

\section{Funding}

This work was primarily supported by the Biotechnology and Biological Sciences Research Council (grant numbers 45/S14995 and BB/G017174/1 to P G Knight). The in vivo study that generated the set of bFF samples analysed in the present study was supported by grants from the University College Dublin, BioResearch Ireland, and the US-Ireland Agricultural Exchange to S I Sunderland; USDA grant numbers 88-37240-4104 and 90-37240-5508, subcontracted from NICHD grant number U54 HD29164; and Research Excellence Funds from Michigan State University (to J J Ireland).

\section{Acknowledgements}

The authors thank Prof. N P Groome (Oxford Brookes University, Oxford, UK) for providing the monoclonal antibodies against FST and activins, Dr A Parlow (NHPP, Torrance, CA, USA) for supplying the ovine LH and recombinant human FST that was used to calibrate the FST ELISA, NIBSC for supplying the recombinant human activin A standard that was used to calibrate the activin A ELISA and Prof. H Sugino (University of Tokushima, Japan) for providing the porcine activin $A B$ that was used to calibrate the activin $A B$ ELISA. We are grateful to Dr C F Kemp for assistance with the Biacore experiments.

\section{References}

Chang C 2008 Agonists and antagonists of the TGF-b family ligands. In The TGF- $\beta$ Family, pp 203-258. Eds R Derynck \& K Miyazono. New York, NY: Cold Spring Harbor Laboratory Press.

Evans LW, Muttukrishna S, Knight PG \& Groome NP 1997 Development, validation and application of a two- site enzyme-linked immunosorbent assay for activin-AB. Journal of Endocrinology 153 221-230. (doi:10.1677/joe.0.1530221)

Fazzini M, Vallejo G, Colman-Lerner A, Trigo R, Campo S, Baranao JL \& Saragueta PE 2006 Transforming growth factor $\beta 1$ regulates follistatin mRNA expression during in vitro bovine granulosa cell differentiation. Journal of Cellular Physiology 207 40-48. (doi:10.1002/jcp.20533)

Findlay JK, Drummond AE, Dyson ML, Baillie AJ, Robertson DM \& Ethier JF 2002 Recruitment and development of the follicle; the roles of the transforming growth factor- $\beta$ superfamily. Molecular and Cellular Endocrinology 191 35-43. (doi:10.1016/S0303-7207(02)00053-9)

Glister C, Tannetta DS, Groome NP \& Knight PG 2001 Interactions between follicle-stimulating hormone and growth factors in modulating secretion of steroids and inhibin-related peptides by nonluteinized bovine granulosa cells. Biology of Reproduction 65 1020-1028. (doi:10.1095/biolreprod65.4.1020)

Glister C, Groome NP \& Knight PG 2003 Oocyte-mediated suppression of follicle-stimulating hormone- and insulin-like growth factor-induced secretion of steroids and inhibin-related proteins by bovine granulosa cells in vitro: possible role of transforming growth factor $\alpha$. Biology of Reproduction 68 758-765. (doi:10.1095/biolreprod.102.008698)

Glister C, Richards SL \& Knight PG 2005 Bone morphogenetic proteins (BMP) $-4,-6$, and -7 potently suppress basal and luteinizing hormone-induced androgen production by bovine theca interna cells in primary culture: could ovarian hyperandrogenic dysfunction be caused by a defect in thecal BMP signaling? Endocrinology 146 1883-1892. (doi:10.1210/en.2004-1303)

Glister C, Groome NP \& Knight PG 2006 Bovine follicle development is associated with divergent changes in activin- $A$, inhibin- $A$ and follistatin and the relative abundance of different follistatin isoforms in follicular fluid. Journal of Endocrinology 188 215-225. (doi:10.1677/joe. 1.06485)

Harrison CA, Chan KL \& Robertson DM 2006 Activin-A binds follistatin and type II receptors through overlapping binding sites: generation of mutants with isolated binding activities. Endocrinology 147 2744-2753. (doi:10.1210/en.2006-0131)

Hashimoto O, Nakamura T, Shoji H, Shimasaki S, Hayashi Y \& Sugino H 1997 A novel role of follistatin, an activin-binding protein, in the inhibition of activin action in rat pituitary cells. Endocytotic degradation of activin and its acceleration by follistatin associated with cell-surface heparan sulfate. Journal of Biological Chemistry 272 13835-13842. (doi:10.1074/jbc.272.21.13835)

Hashimoto O, Kawasaki N, Tsuchida K, Shimasaki S, Hayakawa T \& Sugino H 2000 Difference between follistatin isoforms in the inhibition of activin signalling: activin neutralizing activity of follistatin isoforms is dependent on their affinity for activin. Cellular Signalling 12 565-571. (doi:10.1016/S0898-6568(00)00099-1)

Hedger MP \& de Kretser DM 2013 The activins and their binding protein, follistatin-diagnostic and therapeutic targets in inflammatory disease and fibrosis. Cytokine \& Growth Factor Reviews 24 285-295. (doi:10.1016/ j.cytogfr.2013.03.003) 
Inouye S, Guo Y, DePaolo L, Shimonaka M, Ling N \& Shimasaki S 1991 Recombinant expression of human follistatin with 315 and 288 amino acids: chemical and biological comparison with native porcine follistatin. Endocrinology 129 815-822. (doi:10.1210/endo-129-2-815)

Ireland JJ \& Roche JF 1982 Development of antral follicles in cattle after prostaglandin-induced luteolysis: changes in serum hormones, steroids in follicular fluid, and gonadotropin receptors. Endocrinology 111 2077-2086. (doi:10.1210/endo-111-6-2077)

Keutmann HT, Schneyer AL \& Sidis Y 2004 The role of follistatin domains in follistatin biological action. Molecular Endocrinology 18 228-240. (doi:10.1210/me.2003-0112)

Klein R, Robertson DM, Shukovski L, Findlay JK \& de Kretser DM 1991 The radioimmunoassay of follicle-stimulating hormone (FSH)-suppressing protein (FSP): stimulation of bovine granulosa cell FSP secretion by FSH. Endocrinology 128 1048-1056. (doi:10.1210/endo-128-2-1048)

Knight PG \& Glister C 2001 Potential local regulatory functions of inhibins, activins and follistatin in the ovary. Reproduction 121 503-512. (doi:10. 1530/rep.0.1210503)

Knight PG, Muttukrishna S \& Groome NP 1996 Development and application of a two-site enzyme immunoassay for the determination of 'total' activin-A concentrations in serum and follicular fluid. Journal of Endocrinology 148 267-279. (doi:10.1677/joe.0.1480267)

Knight PG, Satchell L \& Glister C 2012 Intra-ovarian roles of activins and inhibins. Molecular and Cellular Endocrinology 359 53-65. (doi:10. 1016/j.mce.2011.04.024)

Lindsell CE, Misra V \& Murphy BD 1994 Regulation of follistatin gene expression in the ovary and in primary cultures of porcine granulosa cells. Journal of Reproduction and Fertilility 100 591-597. (doi:10.1530/ jrf.0.1000591)

Ludlow H, Phillips DJ, Myers M, McLachlan RI, de Kretser DM, Allan CA, Anderson RA, Groome NP, Hyvonen M, Duncan WC et al. 2009 A new 'total' activin B enzyme-linked immunosorbent assay (ELISA): development and validation for human samples. Clinical Endocrinology 71 867-873. (doi:10.1111/j.1365-2265.2009.03567.x)

Michel U, McMaster JW \& Findlay JK 1992 Regulation of steady-state follistatin mRNA levels in rat granulosa cells in vitro. Journal of Molecular Endocrinology 9 147-156. (doi:10.1677/jme.0.0090147)

Morrissey JH 1981 Silver stain for proteins in polyacrylamide gels: a modified procedure with enhanced uniform sensitivity. Analytical Biochemistry 117 307-310. (doi:10.1016/0003-2697(81)90783-1)

Nakamura T, Sugino K, Titani K \& Sugino H 1991 Follistatin, an activin-binding protein, associates with heparan sulfate chains of proteoglycans on follicular granulosa cells. Journal of Biological Chemistry $26619432-19437$.

Nakamura T, Hashimoto O, Shoji H, Sugino K \& Sugino H 1997 The role of follistatin in activin signal transduction. In Inhibin, Activin and Follistatin: Regulatory Functions in System and Cell Biology, pp 264-276. Sernono Symposia USA. Eds: T Aono, H Sugino, W Vale; Springer-Verlag, New York.

Phillips DJ 2005 Activins, inhibins and follistatins in the large domestic species. Domestic Animal Endocrinology 28 1-16. (doi:10.1016/ j.domaniend.2004.05.006)

Phillips DJ \& de Kretser DM 1998 Follistatin: a multifunctional regulatory protein. Frontiers in Neuroendocrinology 19 287-322. (doi:10.1006/ frne.1998.0169)

Robertson DM 1992 Follistatin/activin-binding protein. Trends in Endocrinology and Metabolism 3 65-68. (doi:10.1016/1043-2760(92)90046-4)
Robertson DM, Klein R, de Vos FL, McLachlan RI, Wettenhall RE, Hearn MT, Burger HG \& de Kretser DM 1987 The isolation of polypeptides with FSH suppressing activity from bovine follicular fluid which are structurally different to inhibin. Biochemical and Biophysical Research Communicatons 149 744-749. (doi:10.1016/0006291X(87)90430-X)

Schneyer AL, Wang QF, Weiss J, Boepple P, Hall J, Khoury R, Taylor A, Pralong F, Sluss PM \& Crowley WF Jr 1997 Follistatin physiology and potential mechanisms of action in the human. In Inhibin, Activin and Follistatin: Regulatory Functions in System and Cell Biology, pp 28-38. Serono Symposia USA. Eds: T Aono, H Sugino, W Vale; Springer-Verlag, New York.

Schneyer A, Schoen A, Quigg A \& Sidis Y 2003 Differential binding and neutralization of activins $A$ and $B$ by follistatin and follistatin like-3 (FSTL-3/FSRP/FLRG). Endocrinology 144 1671-1674. (doi:10.1210/en. 2002-0203)

Shimonaka M, Inouye S, Shimasaki S \& Ling N 1991 Follistatin binds to both activin and inhibin through the common subunit. Endocrinology 128 3313-3315. (doi:10.1210/endo-128-6-3313)

Sugino K, Kurosawa N, Nakamura T, Takio K, Shimasaki S, Ling N, Titani K \& Sugino H 1993 Molecular heterogeneity of follistatin, an activinbinding protein. Higher affinity of the carboxyl-terminal truncated forms for heparan sulfate proteoglycans on the ovarian granulosa cell. Journal of Biological Chemistry 268 15579-15587.

Sugino H, Sugino K, Hashimoto O, Shoji H \& Nakamura T 1997 Follistatin and its role as an activin-binding protein. Journal of Medical Investigation 44 1-14.

Sunderland SJ, Knight PG, Boland MP, Roche JF \& Ireland JJ 1996 Alterations in intrafollicular levels of different molecular mass forms of inhibin during development of follicular- and luteal-phase dominant follicles in heifers. Biology of Reproduction 54 453-462. (doi:10.1095/ biolreprod54.2.453)

Tannetta DS, Feist SA, Bleach EC, Groome NP, Evans LW \& Knight PG 1998 Effects of active immunization of sheep against an amino terminal peptide of the inhibin $\alpha \mathrm{C}$ subunit on intrafollicular levels of activin A, inhibin A and follistatin. Journal of Endocrinology 157 157-168. (doi:10. 1677/joe.0.1570157)

Welt C, Sidis Y, Keutmann H \& Schneyer A 2002 Activins, inhibins, and follistatins: from endocrinology to signaling. A paradigm for the new millennium. Experimental Biology and Medicine 227 724-752.

de Winter JP, ten Dijke P, de Vries CJ, van Achterberg TA, Sugino H, de Waele P, Huylebroeck D, Verschueren K \& van den Eijnden-van Raaij AJ 1996 Follistatins neutralize activin bioactivity by inhibition of activin binding to its type II receptors. Molecular and Cellular Endocrinology 116 105-114. (doi:10.1016/0303-7207(95)03705-5)

Woodruff TK \& Mather JP 1995 Inhibin, activin and the female reproductive axis. Annual Reviews of Physiology 57 219-244. (doi:10.1146/annurev. ph.57.030195.001251)

Received 24 February 2015

First decision 7 April 2015

Revised manuscript received 29 April 2015

Accepted 11 May 2015 